\title{
An investigation of consistency between posterior condylar axis +3 degree external rotation line and clinical transepicondylar axis line techniques in primary total knee arthroplasty
}

\author{
Primer total diz artroplastide arka kondiler aks +3 derece dış rotasyon çizgisi ve \\ klinik transepikondiler aks çizgisi teknikleri arasındaki tutarlıı̆̆ın araştırılması
}

\author{
Hakan Boya, M.D., ${ }^{1}$ Özal Özcan, M.D., ${ }^{2}$ Gökhan Maralcan, M.D. ${ }^{2}$ \\ ${ }^{1}$ Department of Orthopedics and Traumatology, Başkent University Zübeyde Hanım Practice and Research Center, İzmir, Turkey \\ ${ }^{2}$ Department of Orthopedics and Traumatology, Medical Faculty of Afyon Kocatepe University, Afyonkarahisar, Turkey
}

\begin{abstract}
Objectives: This study aims to investigate discrepancy between posterior condylar axis (PCA) +3 degree external rotation (ER) line and clinical transepicondylar axis (cTEA) line and consistency between the both techniques in primary total knee arthroplasty.
\end{abstract}

Patients and methods: Thirty-six knees [Bilateral knees were operated simultaneously in 12 patients $(50 \%)$ ] in 24 patients [3 men (12.5\%), 21 women (87.5\%); average age 67 (59-80 age)] were included in the study. During surgery, $\mathrm{PCA}+3^{\circ}$ ER line and cTEA line were drawn on the distal femoral cutting surface by electrocautery pencil following distal femoral cut. The both lines on distal femur were recorded by digital camera and relationship between lines was ascertained in reference to $\mathrm{PCA}+3^{\circ} \mathrm{ER}$ line [parallel, internal rotation (IR), ER]. Statistical analysis was performed by the McNamara chi square test and Kappa ( $\kappa)$ value.

Results: Assessment of the images revealed that cTEA line in comparison to $\mathrm{PCA}+3^{\circ}$ ER line was parallel in 22 knees $(61.2 \%)$, but not parallel in 14 knees $(38.8 \%)$ [IR in 10 knees (71.5\%), ER in 4 knees $(28.5 \%)]$. There was a significant difference $(\mathrm{McNamara}$ chi square $=12.7 \pm 1 ; \mathrm{p}<0.001)$ and poor consistency $(\kappa=0.00055)$ between both lines and techniques, respectively.

Conclusion: For determination of femoral component rotation in surgery setting, different results between cTEA and $\mathrm{PCA}+3^{\circ}$ ER techniques possibly may due to disadvantages of techniques and anatomic variation of distal femur. Thus, using both techniques to check each other's results seems unsafe.

Key words: Femoral component; femoral transepicondylar axis; posterior condylar axis; rotational alignment; total knee arthroplasty.
Amaç: Bu çalışmada primer total diz protezi uygulamalarında posteriyor kondiler aks (PKA) +3 derece diş rotasyon (DR) çizgisi ve klinik transepikondiler aks (kTEA) çizgisi arasındaki farklılık ve her iki teknik arasındaki tutarlılık araştırıldı.

Hastalar ve yöntemler: Yirmi dört hastanın [3 erkek (\%12.5), 21 kadın (\%87.5); ortalama yaş 67 (59-80 yaş)] 36 dizi [12 hastada her iki diz aynı seansta eşzamanlı olarak ameliyat edildi (\%50)] çalışmaya alındı. Cerrahi sırasında distal femur kesisini takiben kesi yüzeyine koter ucu ile PKA $+3^{\circ}$ DR çizgisi ve kTEA çizgisi çizildi. Distal femur üzerinde bulunan her iki çizgi dijital kamera ile kaydedildi ve $\mathrm{PKA}+3^{\circ}$ DR çizgisi referans alınarak çizgiler arasındaki ilişki araştırıldı [paralel, iç rotasyon (İR), DR]. İstatistiksel analiz McNamara ki

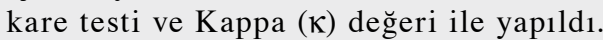

Bulgular: Görüntüler değerlendirildiğinde, kTEA çizgisinin PKA $+3^{\circ}$ DR çizgisine kıyasla 22 dizde (\%61.2) paralel olduğu, 14 dizde ise paralel olmadığ 1 (\%38.8) [10 dizde İR (\%71.5), 4 dizde DR (\%28.5)] tespit edildi. Çizgiler arasında belirgin bir farklıl1k (McNamara ki kare $=12.7 \pm 1$; $<<0.001$ ) ve teknikler arasında düşük oranda tutarlılık $(\kappa=0.00055)$ vardi.

Sonuç: Cerrahi sırasında femoral komponent rotasyonunun tespitinde kullanılan PKA $+3^{\circ}$ DR çizgisi ve kTEA çizgisi arasındaki farklı sonuçlar, olasılıkla tekniklerin uygulama dezavantajlarına ve distal femurun anatomik farklılıklarına bağlıdır. Bu nedenle, iki teknikten birinin diğerinin sonucunu kontrol etmek için kullanılması güvenli değildir.

Anahtar sözcükler: Femoral komponent; femoral transepikondiler aks; arka kondiler aks; rotasyonel hizalanma; total diz protezi.

- Received: July 05, 2013 Accepted: March 13, 2013

- Correspondence: Hakan Boya, M.D. Çatalkaya Mah., Günaydın Sok., Seymen Apt., No: 3/11, 35320 Narlıdere, İzmir, Turkey, Tel: +90 506-343 3668 Fax: +90 232 - 3369421 e-mail: hakanboya@yahoo.com 
Rotational alignment of femoral component (FC) is crucial for long-term survival of total knee arthroplasty (TKA). ${ }^{[1,2]}$ Proper placement of the FC reduces abnormal patella femoral tracking and tibia femoral articulation. $^{[3]}$ There are several different methods/ references described for identification of rotational alignment of FC in primary TKA; Whiteside's line, ${ }^{[4]}$ transepicondylar axis (TEA), ${ }^{[3,5]}$ posterior condylar axis $(\mathrm{PCA})+3^{\circ}$ external rotation (ER), ${ }^{[6]}$ ligament balancing, ${ }^{[5,7]}$ and tibial mechanic axis. ${ }^{[8]}$

Flexion-extension movements of the knee result in an around fixed axis which lies between the origins of collateral ligaments. ${ }^{[9-11]}$ Transepicondylar axis and flexion-extension axis are not completely interchangeable. ${ }^{[12]}$ As both of them are rather nearby, TEA can be used instead of flexion-extension axis of the knee. ${ }^{[10,11,13]}$ Therefore, placement of FC in axial plane should be in parallel with TEA. ${ }^{[10,11,13]}$ In addition, PCA lies in $3^{\circ}$ internal rotation (IR) compare to TEA. ${ }^{[14]}$

Today, modern instrumentation guides which use PCA $\left(+3^{\circ} \mathrm{ER}\right)$ are popular for determination of FC rotation in surgery setting. ${ }^{[15]}$ In our clinical practice, we use these instruments routinely in primary TKA except valgus knees.

This study aims to investigate discrepancy between posterior condylar axis (PCA) +3 degree ER line and clinical TEA (cTEA) line and consistency between the both techniques in primary total knee arthroplasty.

\section{PATIENTS AND METHODS}

This prospective study was approved by Afyon Kocatepe University, Medical Faculty Ethics Committee. Written informed consents were obtained from all participants before surgery. Thirty-six knees in 24 patients ( 3 males, 21 females; mean age 67 years; range 59 to 80 years) which were subsequently operated for severe varus gonarthrosis were included. Both knees were operated simultaneously in $50 \%$ of the patients. During surgery, following distal femoral bone cut, $\mathrm{PCA}+3^{\circ} \mathrm{ER}$ line and CTEA line were drawn on the distal femoral cutting surface by electrocautery pencil. The both lines on distal femur were recorded by digital camera and relationship between lines was ascertained in reference to $\mathrm{PCA}+3^{\circ}$ ER line [parallel, IR and ER] (Figure 1). Statistical analysis was performed using the McNamara chi square test for discrepancy between both lines and Kappa ( $\kappa)$ value for consistency between both techniques.

Femoral components were placed in certain rotational alignment in the axial plane determined with guide instrument using PCA for all cases.

\section{RESULTS}

Assessment of the images revealed that cTEA line in comparison to $\mathrm{PCA}+3^{\circ}$ ER line was parallel in 22 knees $(61.2 \%)$, but not parallel in 14 knees $(38.8 \%)$. Of the non-parallel group, there were 10 knees (71.5\%) with IR and four knees (28.5\%) with ER, respectively. There was a significant difference (McNamara chi square $=12.7 \pm 1 ; \mathrm{p}<0.001$ ) and poor consistency $(\kappa=0.00055)$ between both lines and techniques, respectively.

\section{DISCUSSION}

Total knee arthroplasty is a standard treatment for various disabling disorders of the knee and has proven long-term success. ${ }^{[16]}$ However, it is likely to encounter various complications related with TKA. ${ }^{[17,18]}$ The vast majority of the complications are related to the patellar-femoral joint. ${ }^{[2]}$ Although the implant design is considered effective, the primary reason for failure is improper rotation of $\mathrm{FC}$ in the absence of frontal plane misalignment. ${ }^{[16,19,20]}$ In TKA,
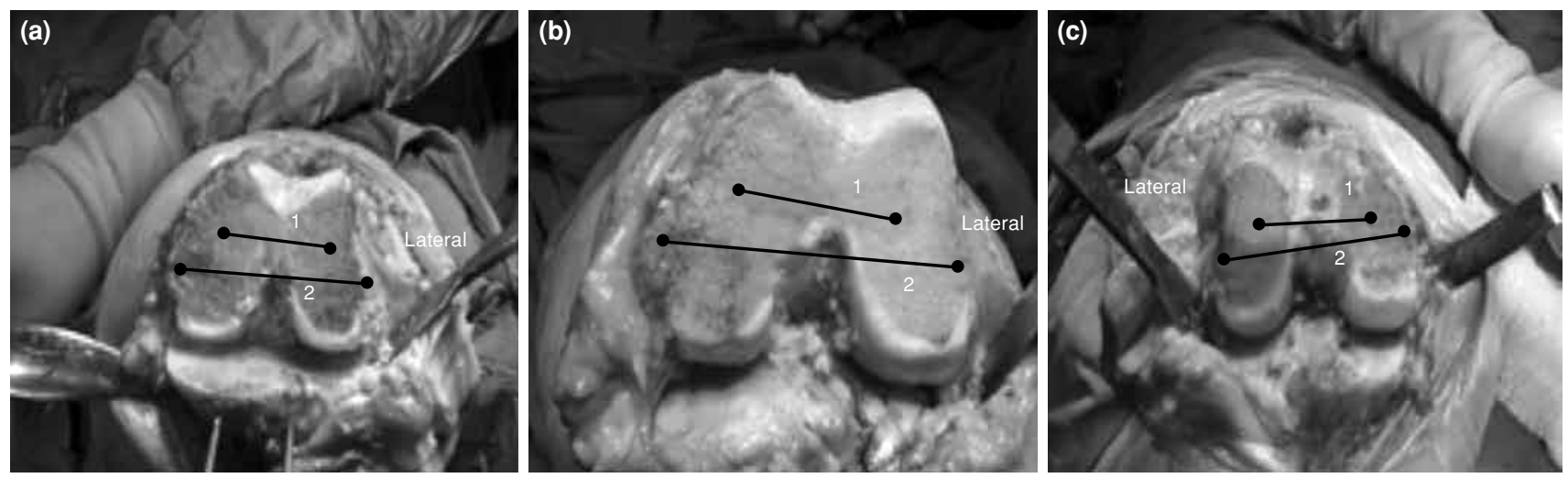

Figure 1. Position of clinical transepicondylar axis line in reference to posterior condylar axis +3 degree external rotation line. (a) Parallel, (b) Internal rotation, (c) External rotation. 1: PCA +3 degree external rotation line; 2: cTEA line. 
FC rotation should be proper for long-term function and survival. ${ }^{[1,2]}$

Transepicondylar axis is a valid reference for determination of the rotation of FC..$^{[3,11,20]}$ Surgical (the most prominent point of lateral epicondyle-medial femoral sulcus) and clinical (the most prominent point of lateral epicondyle - the most prominent point of medial epicondyle) TEAs are distinct concepts (Figure 2). ${ }^{[14]}$ Surgical TEA (sTEA) is accepted as a more accurate reference to determine neutral rotation of FC. ${ }^{[3,11]}$ However, determination of sTEA is challenging. ${ }^{[13,20-23]}$ As the epicondylar peaks obscured by soft tissues, it is difficult to identify precisely in the surgical setting. ${ }^{[9,21,24]}$ In addition, medial sulcus becomes obscure as a result of disease progression in osteoarthritis; it can be detected in only $20 \%$ severely damaged knees. ${ }^{[25]}$ However, most prominent point of the medial epicondyle is detectable in all knees independent of the severity of osteoarthritis. ${ }^{[25]}$ Thus, we used cTEA in this study. Furthermore, the variability between surgeons is high in determination of TEA and establishing femoral rotational alignment is influenced by an individual surgeon's skill. ${ }^{[22]}$

Moreover, PCA lies in $3^{\circ}$ IR compared to sTEA. ${ }^{[14]}$ Thus, $\mathrm{PCA}+3^{\circ}$ ER line in the surgical setting is determined using guide instruments. It is accepted that the line is in parallel with sTEA. ${ }^{[1,15]}$ Improper placement of the guide instrument, anatomic variability of distal femoral condyle, bone and cartilage wearing of posterior femoral condyle due to severe osteoarthritis and valgus knee are common problems related with this method. ${ }^{[2,4,26]}$ Also, there are studies that suggested and refused any relationship between sex and the anatomic angle in PCA and TEA. ${ }^{[3,14]}$

Surgical TEA is more consistent than PCA $+3^{\circ}$ ER line to produce balanced flexion gap. ${ }^{[7,27]}$ Preoperative alignment of the knee directly influences the accuracy of these techniques. ${ }^{[24,27]}$ In addition, TEA is the most viable reference used for this purpose; however,

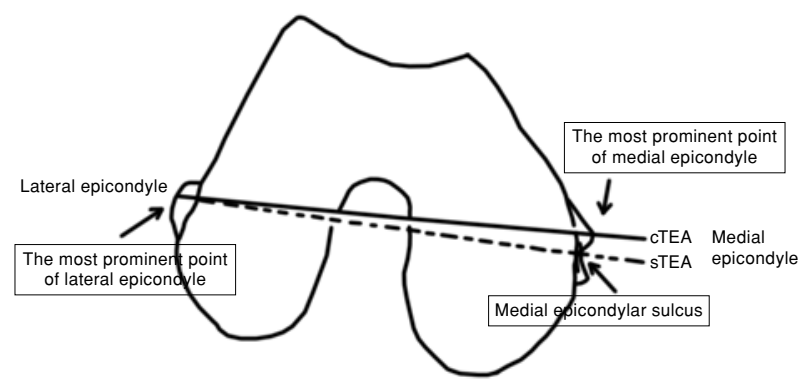

Figure 2. Surgical transepicondylar axis (STEA) and clinical transepicondylar axis (cTEA). it is unlikely to produce flexion gap stability in neutral/varus knees and valgus knees in $10 \%$ and $14 \%$, respectively. ${ }^{[27]}$ Any single method used to determine rotation carries at least a $10 \%$ change of creating flexion gap asymmetry, therefore, it is better to use more than one method of femoral rotation alignment. ${ }^{[7,27]}$ There were also reports indicating a wide variety between PCA and cTEA/sTEA. ${ }^{[3,14,21,24]}$ This variety is possibly due to the disadvantages of each technique including anatomic variation of the distal femur primarily. ${ }^{[12]}$ Although knowing details of more than one technique for determination of FC rotation has been suggested, almost all techniques have a wide error interval. ${ }^{[28]}$ Therefore, it still remains unknown how much variability in the axial femoral alignment can be tolerated. ${ }^{[29]}$ In surgery setting, reproducing of FC absolute rotation should be the main purpose.

In our study, a statistically significant discrepancy was determined between CTEA and PCA $+3^{\circ}$ ER lines $(p<0.001)$, and consistency between these techniques was extremely poor $(\kappa=0.00055)$. At first, it is believed that this was caused by the disadvantages of the techniques, however, possibly anatomic variation of distal femur was the main cause. Another cause of differences between techniques may be an external rotation position of CTEA in respect to STEA.

On the other hand, limitations of our study include small sample size and lack of quantitative assessment of the relationship between cTEA and $\mathrm{PCA}+3^{\circ}$ ER lines. Prospective studies in a larger patient population with severe gonarthrosis will provide valuable clinical information regarding determination of femoral component rotation in surgery setting. We determined a relationship between the lines with qualitative assessment, therefore, it is impossible to know the certain degrees of incoordinate.

There is at least $10 \%$ change of creating improper femoral component rotation if one of the methods developed to determine the rotation use alone, therefore, it is better to use more than one method simultaneously intraoperatively. ${ }^{[7,27]}$ In addition, TEA and $\mathrm{PCA}+3^{\circ}$ ER techniques are frequently used to determine the rotation in surgery setting. ${ }^{[3,5,6]}$

In conclusion, we focused on the both methods in our study. Previous studies evaluated angular relationship between s/cTEA and PCA with only mean values and standard deviation or compared different axial references to PCA statistically, however, our study statistically ascertained consistency and discrepancy between the both (cTEA/PCA $+3^{\circ}$ ER) techniques and lines, respectively (Table I). For determination 
TABLE I

Review of study characteristics from published articles

\begin{tabular}{|c|c|c|c|c|}
\hline References & Study type & Evaluation & Statistics & Outcome \\
\hline \multirow[t]{2}{*}{ Berger et al. ${ }^{[3]}$} & \multirow[t]{2}{*}{ Anatomic cadaver study } & $\begin{array}{c}\text { Angle between cTEA and PCA } \\
4.7^{\circ} \pm 3.5^{\circ}{ }^{\wedge} \\
5.2^{\circ} \pm 4.1^{\circ} \circ\end{array}$ & \multirow[t]{2}{*}{$\begin{array}{l}\text { Mean values with standard } \\
\text { deviation }\end{array}$} & \multirow[t]{2}{*}{$\begin{array}{c}\text { sTEA method is useful to } \\
\text { orient FC }\end{array}$} \\
\hline & & $\begin{array}{c}\text { Angle between sTEA and PCA } \\
3.5^{\circ} \pm 1.2^{\circ} 0^{\wedge} \\
0.3^{\circ} \pm 1.2^{\circ} \stackrel{9}{q}\end{array}$ & & \\
\hline \multirow[t]{2}{*}{ Arima et al. ${ }^{[21]}$} & \multirow[t]{2}{*}{ Anatomic cadaver study } & $\begin{array}{l}\text { Angle between cTEA and PCA } \\
4.4^{\circ} \pm 2.9^{\circ}\end{array}$ & \multirow{2}{*}{$\begin{array}{c}\text { Mean values with standard } \\
\text { deviation } \\
\text { Student t-test }\end{array}$} & \multirow{2}{*}{$\begin{array}{l}\text { AP axis method appears } \\
\text { to be more reliable and is } \\
\text { certainly easier to use than } \\
\text { TEA method }\end{array}$} \\
\hline & & $\begin{array}{l}\text { Discrepancy between CTEA and } \\
\text { Whiteside line reference to PCA }\end{array}$ & & \\
\hline Poilvache et al. ${ }^{[24]}$ & $\begin{array}{c}\text { Clinical } \\
\text { (Intraoperative measurement) }\end{array}$ & $\begin{array}{c}\text { Angle between cTEA and PCA } \\
3.51^{\circ} \pm 2.03^{\circ} \\
\text { Varus-neutral knees }\end{array}$ & $\begin{array}{l}\text { Mean values with standard } \\
\text { deviation }\end{array}$ & $\begin{array}{l}\text { Angle between cTEA and } \\
\text { PCA is important to orient } \\
\text { FC }\end{array}$ \\
\hline \multirow[t]{2}{*}{ Olcott and $S \operatorname{cott}^{[27]}$} & \multirow[t]{2}{*}{$\begin{array}{c}\text { Clinical } \\
\text { (Intraoperative measurement) }\end{array}$} & \multirow{2}{*}{$\begin{array}{l}\text { Consistency of } \mathrm{PCA}+3^{\circ} \mathrm{ER}, \\
\text { Whiteside line, cTEA methods } \\
\text { reference to tibial mechanic axis } \\
\text { Varus-neutral knees } \\
\text { cTEA }>\text { Whiteside line> } \mathrm{PCA}+3^{\circ} \mathrm{ER}\end{array}$} & $\begin{array}{c}\text { Mean values with standard } \\
\text { deviation }\end{array}$ & \multirow{2}{*}{$\begin{array}{l}\text { Do not use only one method } \\
\text { for rotational alignment of } \\
\text { FC }\end{array}$} \\
\hline & & & Paired t-test & \\
\hline Griffin et al. ${ }^{[14]}$ & Radiological (MRI) & $\begin{array}{c}\text { Angle between sTEA and PCA } \\
3.11^{\circ} \pm 1.7^{\circ}\end{array}$ & $\begin{array}{c}\text { Mean values with standard } \\
\text { deviation }\end{array}$ & $\begin{array}{c}\mathrm{PCA}+3^{\circ} \text { ER method is } \\
\text { unsafe }\end{array}$ \\
\hline \multirow[t]{2}{*}{ Katz et al..$^{[12]}$} & \multirow[t]{2}{*}{ Anatomic cadaver study } & $\begin{array}{l}\text { Angle between cTEA and PCA } \\
6.1^{\circ} \pm 3.3^{\circ}\end{array}$ & $\begin{array}{c}\text { Mean values with standard } \\
\text { deviation }\end{array}$ & \multirow{2}{*}{$\begin{array}{l}\text { CTEA provide more } \\
\text { external rotation in reference } \\
\text { to } \mathrm{PCA}+3^{\circ} \mathrm{ER} \text { for } \mathrm{FC} \text { than } \\
\text { other methods }\end{array}$} \\
\hline & & $\begin{array}{l}\text { CTEA, Whiteside line, LB methods } \\
\text { results discrepancy reference to } \\
\text { PCA }\end{array}$ & ANOVA, Student's t-test & \\
\hline \multirow[t]{2}{*}{ The study } & \multirow[t]{2}{*}{$\begin{array}{c}\text { Clinical } \\
\text { (Intraoperative measurement) }\end{array}$} & $\begin{array}{l}\text { Discrepancy between cTEA and } \\
\text { PCA }+3^{\circ} \text { ER lines }\end{array}$ & McNamara Chi square test & \multirow{2}{*}{$\begin{array}{l}\text { Using the both techniques } \\
\text { for check each other's } \\
\text { results seems unsafe }\end{array}$} \\
\hline & & $\begin{array}{l}\text { Consistency between the both } \\
\text { technique }\end{array}$ & Kappa (к) value & \\
\hline
\end{tabular}

CTEA: Clinical transepicondylar axis; PCA: Posterior condylar axis; sTEA: Surgical transepicondylar axis; FC: Femoral component; TEA: Transepicondylar axis; ER: External rotation; MRI: Magnetic resonance imaging; LB: Ligament balancing.

of FC rotation in surgery setting, different results between cTEA and $\mathrm{PCA}+3^{\circ}$ ER techniques possibly may be due to disadvantages of techniques and anatomic variation of distal femur. Thus, using both techniques for check each other's results seems unsafe. Undoubtedly, it is possible to determine the angular relationship between PCA and surgical/clinical TEA radiologically (computed tomography) preoperatively. Carrying this knowledge to intraoperative setting by using adjustable instrumentation guide rather than standard instrumentation guide which has fixed $+3^{\circ}$ ER may be an ideal method of choice.

\section{Declaration of conflicting interests}

The authors declared no conflicts of interest with respect to the authorship and/or publication of this article.

\section{Funding}

The authors received no financial support for the research and/or authorship of this article.

\section{REFERENCES}

1. Akagi M, Matsusue $\mathrm{Y}$, Mata T, Asada $\mathrm{Y}$, Horiguchi M, Iida $\mathrm{H}$, Nakamura T. Effect of rotational alignment on patellar tracking in total knee arthroplasty. Clin Orthop Relat Res 1999;336:155-63.

2. Anouchi YS, Whiteside LA, Kaiser AD, Milliano MT. The effects of axial rotational alignment of the femoral component on knee stability and patellar tracking in total knee arthroplasty demonstrated on autopsy specimens. Clin Orthop Relat Res 1993;287:170-7.

3. Berger RA, Rubash HE, Seel MJ, Thompson WH, Crossett LS. Determining the rotational alignment of the femoral component in total knee arthroplasty using the epicondylar axis. Clin Orthop Relat Res 1993;286:40-7.

4. Whiteside LA, Arima J. The anteroposterior axis for femoral rotational alignment in valgus total knee arthroplasty. Clin Orthop Relat Res 1995;321:168-72.

5. Insall JN, Binazzi R, Soudry M, Mestriner LA. Total knee arthroplasty. Clin Orthop Relat Res 1985;192:13-22.

6. Laskin RS. Flexion space configuration in total knee arthroplasty. J Arthroplasty 1995;10:657-60.

7. Olcott CW, Scott RD. Determining proper femoral component rotational alignment during total knee arthroplasty. Am J Knee Surg 2000;13:166-8.

8. Stiehl JB, Abbott BD. Femoral component rotational 
alignment using the extramedullary tibial shaft axis: A technical note. J Orthop Rheumatol 1995;8:93-6.

9. Churchill DL, Incavo SJ, Johnson CC, Beynnon BD. The transepicondylar axis approximates the optimal flexion axis of the knee. Clin Orthop Relat Res 1998;356:111-8.

10. Hollister AM, Jatana S, Singh AK, Sullivan WW, Lupichuk AG. The axes of rotation of the knee. Clin Orthop Relat Res 1993;290:259-68.

11. Yoshioka Y, Siu D, Cooke TD. The anatomy and functional axes of the femur. J Bone Joint Surg [Am] 1987;69:873-80.

12. Katz MA, Beck TD, Silber JS, Seldes RM, Lotke PA. Determining femoral rotational alignment in total knee arthroplasty: reliability of techniques. J Arthroplasty 2001;16:301-5.

13. Akagi M, Yamashita E, Nakagawa T, Asano T, Nakamura T. Relationship between frontal knee alignment and reference axes in the distal femur. Clin Orthop Relat Res 2001;388:147-56.

14. Griffin FM, Math K, Scuderi GR, Insall JN, Poilvache PL. Anatomy of the epicondyles of the distal femur: MRI analysis of normal knees. J Arthroplasty 2000;15:354-9.

15. Berger RA, Rubash HE. Rotational instability and malrotation after total knee arthroplasty. Orthop Clin North Am 2001;32:639-47.

16. Insall JN, Kelly M. The total condylar prosthesis. Clin Orthop Relat Res 1986;205:43-8.

17. Ozcan O, Boya H, Ateş A, Doğruöz F. Bilateral periprosthetic distal femoral fractures following total knee arthroplasty. Eklem Hastalik Cerrahisi 2013;24:178-81.

18. Erkan S, Yercan HS, Okcu G, Ozalp RT. Factors causing stiff knee after total knee arthroplasty. [Article in Turkish] Eklem Hastalik Cerrahisi 2011;22:16-21.

19. Dennis DA. Patellofemoral complications in TKA: A literature review. Am J Knee Surg 1992;5:156-66.
20. Siston RA, Patel JJ, Goodman SB, Delp SL, Giori NJ. The variability of femoral rotational alignment in total knee arthroplasty. J Bone Joint Surg [Am] 2005;87:2276-80.

21. Arima J, Whiteside LA, McCarthy DS, White SE. Femoral rotational alignment, based on the anteroposterior axis, in total knee arthroplasty in a valgus knee. A technical note. J Bone Joint Surg [Am] 1995;77:1331-4.

22. Jenny JY, Boeri C. Low reproducibility of the intra-operative measurement of the transepicondylar axis during total knee replacement. Acta Orthop Scand 2004;75:74-7.

23. Jerosch J, Peuker E, Philipps B, Filler T. Interindividual reproducibility in perioperative rotational alignment of femoral components in knee prosthetic surgery using the transepicondylar axis. Knee Surg Sports Traumatol Arthrosc 2002;10:194-7.

24. Poilvache PL, Insall JN, Scuderi GR, Font-Rodriguez DE. Rotational landmarks and sizing of the distal femur in total knee arthroplasty. Clin Orthop Relat Res 1996;331:35-46.

25. Yoshino N, Takai S, Ohtsuki Y, Hirasawa Y. Computed tomography measurement of the surgical and clinical transepicondylar axis of the distal femur in osteoarthritic knees. J Arthroplasty 2001;16:493-7.

26. Griffin FM, Insall JN, Scuderi GR. The posterior condylar angle in osteoarthritic knees. J Arthroplasty 1998;13:812-5.

27. Olcott CW, Scott RD. A comparison of 4 intraoperative methods to determine femoral component rotation during total knee arthroplasty. J Arthroplasty 2000;15:22-6.

28. Yau WP, Chiu KY, Tang WM. How precise is the determination of rotational alignment of the femoral prosthesis in total knee arthroplasty: an in vivo study. J Arthroplasty 2007;22:1042-8.

29. Stöckl B, Nogler M, Rosiek R, Fischer M, Krismer M, Kessler O. Navigation improves accuracy of rotational alignment in total knee arthroplasty. Clin Orthop Relat Res 2004;426:180-6. 